Article

\title{
Dual RNA Sequencing of Vitis vinifera during Lasiodiplodia theobromae Infection Unveils Host-Pathogen Interactions
}

\author{
Micael F. M. Gonçalves ${ }^{1}{ }^{(}$, Rui B. Nunes ${ }^{1}$, Laurentijn Tilleman ${ }^{2}{ }^{\circledR}$, Yves Van de Peer ${ }^{3,4,5}{ }^{(\mathbb{D}}$, \\ Dieter Deforce ${ }^{2}$, Filip Van Nieuwerburgh ${ }^{2}$, Ana C. Esteves ${ }^{6}$ and Artur Alves ${ }^{1, *(1)}$ \\ 1 Department of Biology, CESAM, University of Aveiro, 3810-193 Aveiro, Portugal; mfmg@ua.pt (M.F.M.G.); \\ r.nunesbarros@ua.pt (R.B.N.) \\ 2 Laboratory of Pharmaceutical Biotechnology, Campus Heymans, Ottergemsesteenweg 460, B-9000 Ghent, \\ Belgium; Laurentijn.Tilleman@ugent.be (L.T.); dieter.deforce@ugent.be (D.D.); \\ Filip.VanNieuwerburgh@ugent.be (F.V.N.) \\ 3 Department of Plant Biotechnology and Bioinformatics, Ghent University, 9052 Ghent, Belgium; \\ yves.vandepeer@psb.vib-ugent.be \\ 4 Center for Plant Systems Biology, VIB, 9052 Ghent, Belgium \\ 5 Department of Biochemistry, Genetics and Microbiology, University of Pretoria, Pretoria 0028, South Africa \\ 6 Faculty of Dental Medicine, Center for Interdisciplinary Research in Health (CIIS), Universidade Católica \\ Portuguesa, Estrada da Circunvalação, 3504-505 Viseu, Portugal; acesteves@viseu.ucp.pt \\ * Correspondence: artur.alves@ua.pt; Tel.: +351-234-370-766
}

Received: 28 October 2019; Accepted: 29 November 2019; Published: 3 December 2019

\begin{abstract}
Lasiodiplodia theobromae is one of the most aggressive agents of the grapevine trunk disease Botryosphaeria dieback. Through a dual RNA-sequencing approach, this study aimed to give a broader perspective on the infection strategy deployed by L. theobromae, while understanding grapevine response. Approximately $0.05 \%$ and $90 \%$ of the reads were mapped to the genomes of L. theobromae and Vitis vinifera, respectively. Over 2500 genes were significantly differentially expressed in infected plants after $10 \mathrm{dpi}$, many of which are involved in the inducible defense mechanisms of grapevines. Gene expression analysis showed changes in the fungal metabolism of phenolic compounds, carbohydrate metabolism, transmembrane transport, and toxin synthesis. These functions are related to the pathogenicity mechanisms involved in plant cell wall degradation and fungal defense against antimicrobial substances produced by the host. Genes encoding for the degradation of plant phenylpropanoid precursors were up-regulated, suggesting that the fungus could evade the host defense response using the phenylpropanoid pathway. The up-regulation of many distinct components of the phenylpropanoid pathway in plants supports this hypothesis. Moreover, genes related to phytoalexin biosynthesis, hormone metabolism, cell wall modification enzymes, and pathogenesis-related proteins seem to be involved in the host responses observed. This study provides additional insights into the molecular mechanisms of $L$. theobromae and $V$. vinifera interactions.
\end{abstract}

Keywords: dual RNA-Seq; grapevine; botryosphaeria dieback; plant defense; pathogenesis

\section{Introduction}

Grapevine (Vitis vinifera) is widely cultivated and an economically important fruit crop worldwide [1]. Diseases of fungal origin such as grapevine trunk diseases (GTDs) are a significant factor limiting grapevine productivity and longevity $[2,3]$. Botryosphaeria dieback caused by the fungi of the family Botryosphaeriaceae that grow primarily in mature wood causes dieback as a consequence of the development of a necrotic wood canker/lesion [3]. Botryosphaeria dieback leads to a loss of 
productivity, reducing profit and longevity [4]. Some authors suggest that environmental changes, such as drought and increase of temperature, may induce some fungi to become aggressive pathogens, killing their hosts through the release of cell wall degrading enzymes, inhibitory proteins, and toxins [5-8].

Lasiodiplodia theobromae is a common phytopathogenic fungus and one of the most aggressive species found in grapevines [1,9-11]. It is mostly found in tropical and subtropical regions $[12,13]$ and has an optimal temperature range of $27^{\circ} \mathrm{C}-33^{\circ} \mathrm{C}$ [14]. This pathogen has a great adaptation capacity and has been associated with numerous hosts and diseases [13]. Although it is more frequent in grape-growing regions with high temperatures and low precipitation [9-11], it has also been reported in temperate climates [15-18].

The interaction between plants and their pathogens is a dynamic and complex process. These interactions should be analyzed as a duel process, and the plant's reactions should not be separated from the ones of the pathogen [19]. When a pathogen interacts with its host, it will trigger a complex host defense response activating various processes, such as penetration resistance, recognition by pattern recognition receptors (PRRs), phytohormone signaling pathways, secretory pathways, and secondary metabolite production [20]. RNA sequencing (RNA-Seq) is a powerful technology that has been widely implemented to investigate host defense mechanisms during infection. So far, this approach has been applied mainly to the host or to the pathogen separately [19]. Dual RNA sequencing allows the study of both host and pathogen transcriptomes simultaneously, detecting pathogen-specific transcripts in the same sample, providing a more complete insight into the pathogen infection biology and host defense mechanisms $[19,21,22]$. This approach has already been applied in a few studies of plant-pathogen interactions in crops [23-26] and trees [20,27,28].

Using a dual RNA-Seq approach, we aimed to identify the pathogenicity factors produced by $L$. theobromae and determine the V. vinifera defense responses to the pathogen. Overall, we intended to contribute to unraveling host-pathogen interactions and provide helpful information for the future development of strategies of disease control and management.

\section{Results}

\subsection{Macroscopic Analysis}

Progression of necrosis was observed throughout the duration of the experiment (Figure 1). No lesions beyond the wound site were observed in "mock" inoculated plants in all sampling points. At 1 day post-inoculation (dpi), no lesions related to fungal infection were observed. After $3 \mathrm{dpi}$, a slight browning around the inoculation sites in inoculated plants was observed $(0.5 \pm 0.1 \mathrm{~cm})$. At $7 \mathrm{dpi}$, the lesion in infected plants progressed $(5 \pm 0.2 \mathrm{~cm})$, and at $10 \mathrm{dpi}$, the lesion length was intensified, covering $9 \pm 0.2 \mathrm{~cm}$ in length.

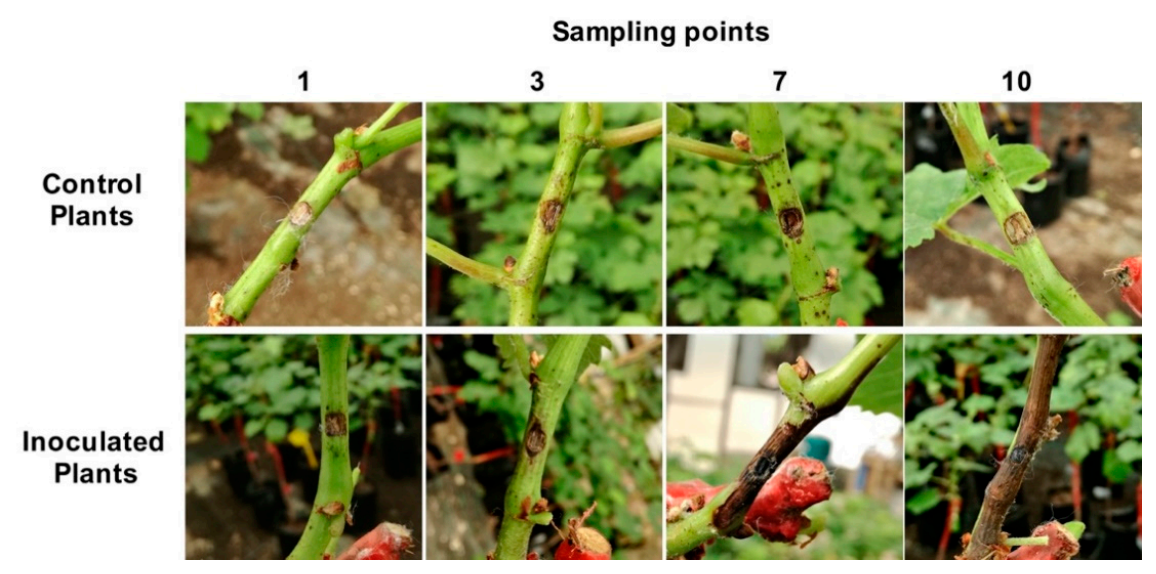

Figure 1. Symptom development in $V$. vinifera following $L$. theobromae inoculation for $1,3,7$, and 10 days post-inoculation. 


\subsection{Dual RNA-Seq Analysis}

To characterize the responses of $V$. vinifera to L. theobromae infection in the green shoots, and simultaneously to characterize gene expression of L. theobromae during the process, we profiled both transcriptomes using a dual RNA-Seq approach at the four time points described above. Reads were mapped to the combined reference genomes of grapevine (V. vinifera var. "PN40024") and of L. theobromae (NCBI SAMN08892999). Considering all samples, $15 \pm 4$ million reads were mapped to the $V$. vinifera genome. Considering the infected samples, $11 \pm 7$ thousand reads were mapped to the L. theobromae genome. Saturation curves (Figure S1) show that most genes of the V. vinifera genome were sequenced in all the samples, representing an adequate library complexity and sequencing depth. Saturation was not achieved for L. theobromae genes in the infected samples (Figure S2), i.e., we have not sequenced enough to discover all the L. theobromae genes. However, this does not mean that no differential expression gene analysis can be performed. A total of 23,417 and 7115 genes were identified for $V$. vinifera and L. theobromae, respectively. Only genes present in at least three replicates with a minimum of one count per million (cpm) were used for differential expression analysis. In this way, 18,062 and 4095 genes of $V$. vinifera and L. theobromae, respectively, were considered as quantifiable genes.

\subsection{Differentially Expressed Genes (DEGs) in V. vinifera}

Differential gene expression analysis of $V$. vinifera inoculated with $L$. theobromae compared to control resulted in a total of $0,331,374$, and 2718 DEG at 1,3, 7, and 10 dpi, respectively (Figure 2A). For each time point, there was a higher number of up-regulated genes than down-regulated genes. The most extensive transcriptional reprogramming caused by infection was observed in stems at 10 dpi. A total of 69,48 , and 2203 DEGs were specific for 3, 7, and 10 dpi, respectively, while 71 DEG were common to all sampling points (Figure 2B). To associate the DEGs to a function, the sequence of the DEGs were BLASTed against the UniProtKB/Swiss-Prot database with an e-value of $10^{\mathrm{E}-10}$ (Tables S1-S3) [29,30].
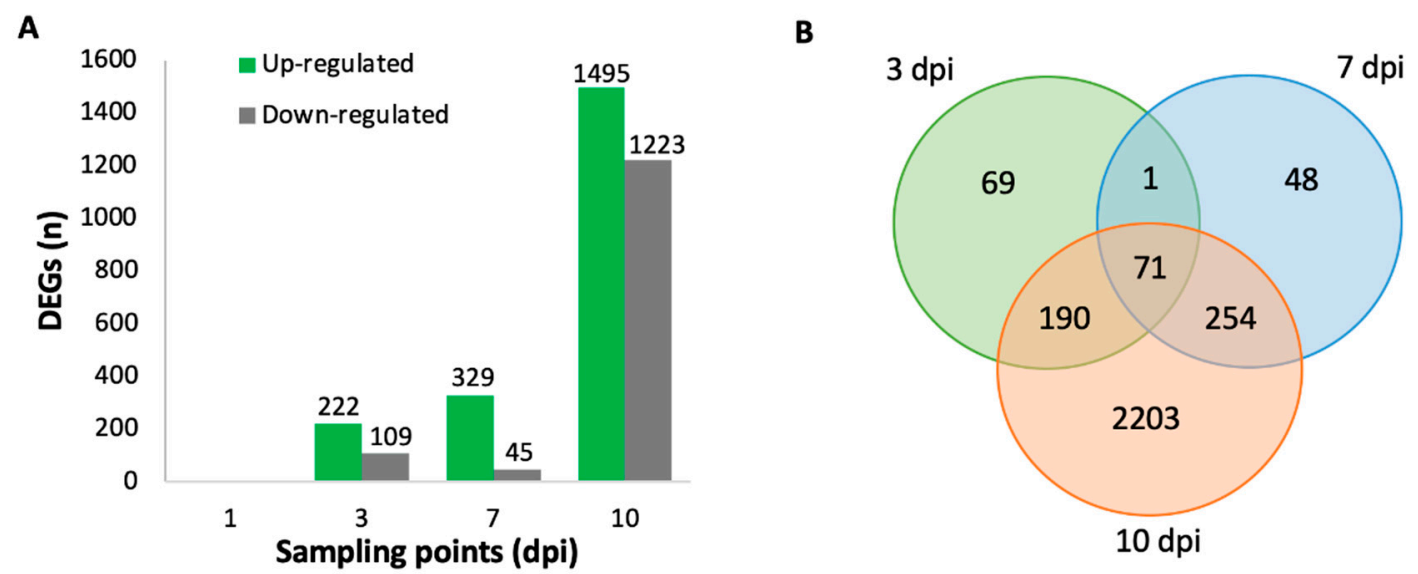

Figure 2. (A) Number of up-regulated and down-regulated significantly differentially expressed genes (false discovery rate, FDR $<0.01$ and a $\log _{2}$ fold change $(F C)>1$ or $<-1$ ) in $V$. vinifera after inoculation with L. theobromae compared to control for 1,3, 7, and 10 days post-inoculation. Only genes present in all replicates were taken into account. (B) Venn diagram of differentially expressed genes among the three time points ( 3 vs. 7 vs. $10 \mathrm{dpi}$ ).

\subsection{Predominant Functions (GO) of V. vinifera DEGs during L. theobromae Infection}

The functions of the DEGs based on Gene Ontology (GO) analysis are listed in Tables S1-S3. Significant biological processes were obtained via GO terms enrichment analysis. Up- and down-regulated genes enriched in each GO term are shown in Figures 3 and 4 within the significantly affected (false discovery rate, FDR) $<0.05$ ). The complete list can be found in Table S4. 
The results showed that $L$. theobromae affected several genes down-regulated in $V$. vinifera involved in photosynthesis, cell wall and cytoskeleton organization, transport, and cell cycle. Most of the enriched terms of up-regulated genes are involved in defense response, secondary metabolites, sterol and phenylpropanoid biosynthesis, and response to oxidative stress.

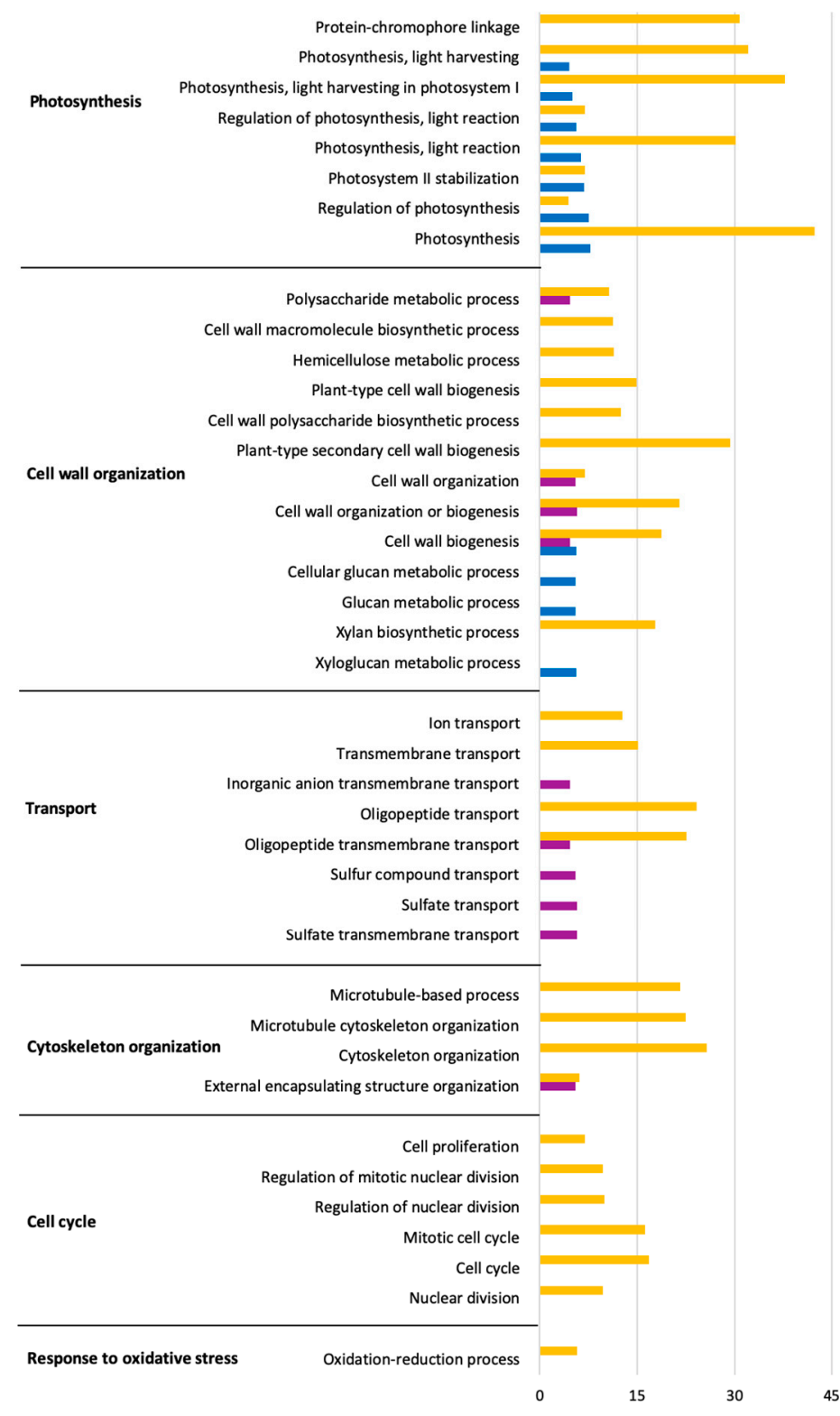

Figure 3. Gene Ontology (Biological process) enrichment analysis of down-regulated genes in response to L. theobromae inoculation in V. vinifera at 3 (blue), 7 (purple), and 10 (orange) dpi. The $x$-axes represent the absolute $\log _{2}$ (q-value) based on hypergeometric distribution followed by false discovery rate correction (FDR $<0.05)$. 


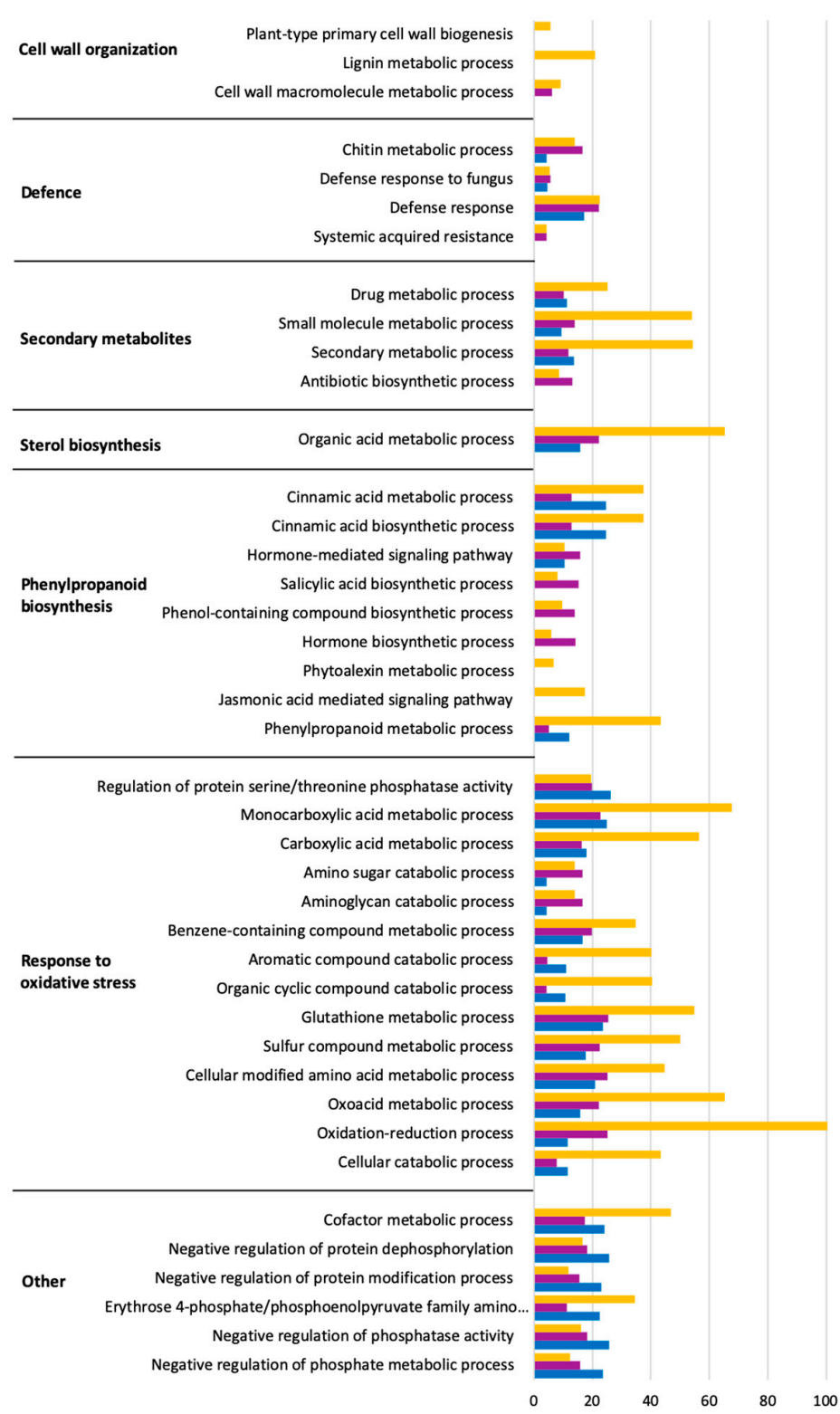

Figure 4. Gene Ontology (Biological process) enrichment analysis of up-regulated genes in response to L. theobromae inoculation in $V$. vinifera at 3 (blue), 7 (purple), and 10 (orange) dpi. The $x$-axes represent the absolute $\log _{2}$ (q-value) based on hypergeometric distribution followed by false discovery rate correction (FDR < 0.05).

\subsection{Time Series Analysis of V. vinifera Genes}

A total of 1269 out of the 12,841 temporal DEGs in the time series analysis of the $V$. vinifera genes was fitted with a regression model with an $\mathrm{R}^{2}>0.8$ and were used for cluster analysis. Twelve clusters were defined (Figure 5, Table S5). Each cluster contains genes that have similar expression profiles following the same trend along time. Clusters 3, 4, 5, 6, 9, 10, and 11 (with 112, 199, 84, 243, 83,80 , and 64 genes, respectively) contain transcripts up-regulated in the inoculated plants at all time points. These transcripts encode glutathione transferases (GSTs), cytochrome P450 oxygenases, pleiotropic drug resistance (PDR) transporters, pathogenesis-related (PR) proteins, thaumatin-like proteins (TLPs), stilbene synthase (STS), chalcone synthase (CHS), phenylalanine ammonia lyase (PAL), flavonoid biosynthesis, calmodulin-like proteins, endochitinases, and pectinesterases. On the other hand, Clusters 1, 7, and 8 (with 186, 92, and 50 genes) contain fewer abundant genes in the inoculated plants at all time points. The expression of genes in cluster 1 decreases from Days 1 to 
7 in the inoculated plants, and it increases between 7 and 10 dpi. Cluster 1 genes exhibit the same expression level in the control conditions. Cluster 2 shows genes whose expression increases over time, both in the inoculated plants and in the control plants. However, the median expression of these genes in the inoculated plants is clearly overtaking the expression of these genes in the control plants after 3 dpi. Clusters 3, 11, and 12 include genes whose expression decreases over time, both in inoculated and in control plants. The expression of genes in Cluster 4 increases through time in the inoculated plants but remains stable in control conditions. Cluster 5 shows genes whose expression increases along time in inoculated plants, while there was no expression in control plants. The expression of genes in Cluster 6 increases during time but decreases from Day 7 until the end of the experiment in inoculated plants. In control plants, the genes remained at the same expression level. Cluster 7 includes genes whose expression increases only after $7 \mathrm{dpi}$ both in inoculated and control plants, while the expression of genes in Cluster 8 increases over time and decreases from Day 7. The expression of genes in Clusters 9 and 10 increases until Day 3 but show a decrease between 3 and $7 \mathrm{dpi}$ in both conditions.
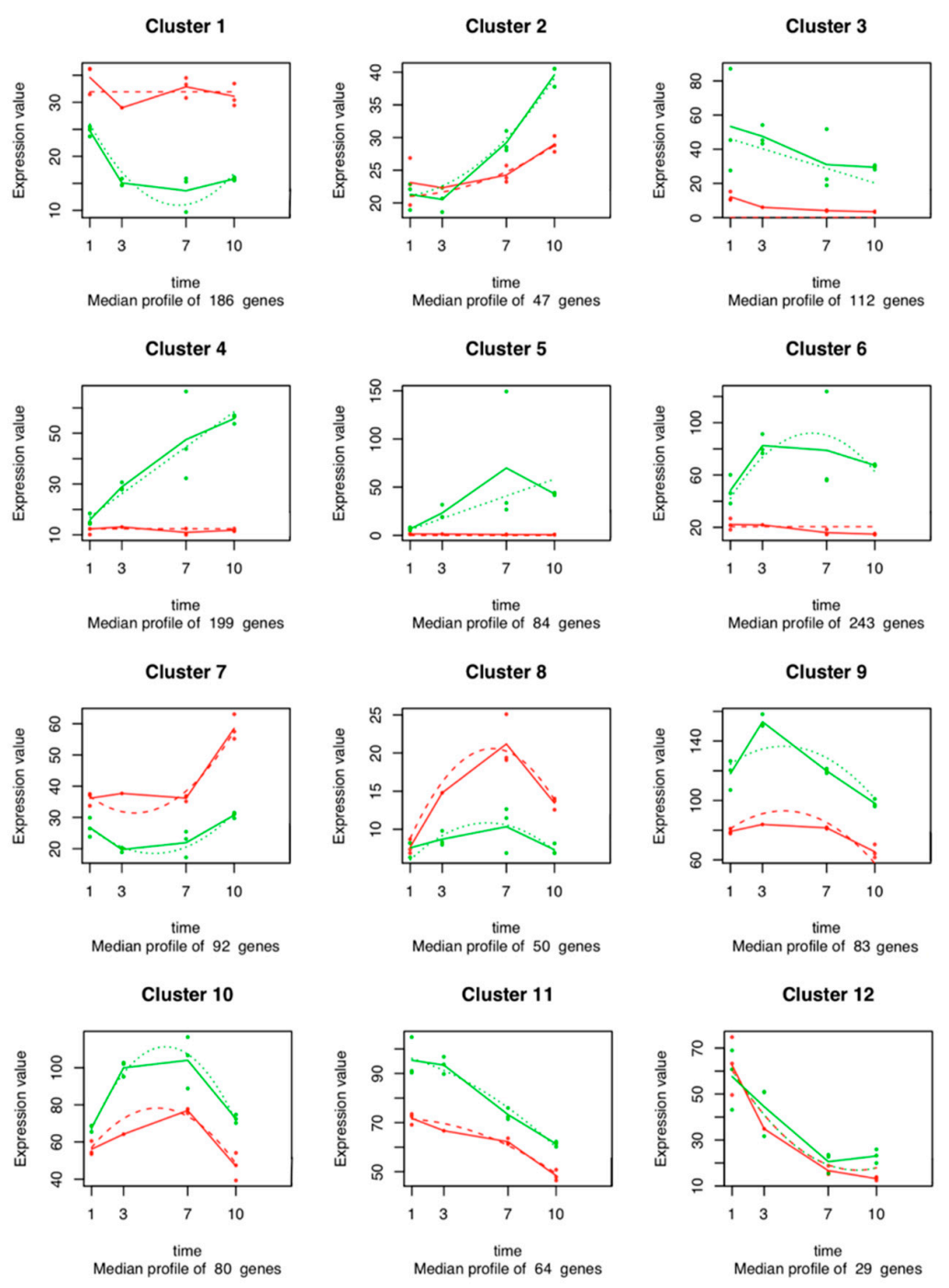

Figure 5. Expression profiles of the V. vinifera gene clusters sharing a similar expression pattern during the infection of grapevine stems. In each graph, the dots show the median expression value (i.e., normalized count) of the genes in the cluster for each biological replicate at each time point. The solid red (control group) and green (inoculated plants) lines connect the median of these median expression values at each time point. Dashed lines represent the fitted regression model that was performed on each cluster, modeling the relationship between median expression values of the cluster and the time points. 


\subsection{Inducible Defence Mechanisms during L. theobromae Infection}

One of the noteworthy aspects of the RNA-Seq data obtained was that several PR genes were particularly differentially expressed-mostly up-regulated-with high fold-change values (Tables S1-S3 and S5). The most prominent PR genes were PR-3 (chitinase I and IV), PR-4 (chitin-binding) (e.g., Chi4C, VIT_15s0046g01590, VIT_15s0046g01600, VIT_05s0094g00330, VIT_11s0149g00280, VIT_05s0094g00260, and VIT_14s0081g00050), PR-5 (thaumatin-like) (e.g., VIT_02s0025g04300, VIT_13s0019g02020,VIT_14s0066g02130, and VIT_17s0000g02470), and PR-10 (ribonuclease-like) (e.g., PR10.2, PR10.3, VIT_05s0077g01530,VIT_05s0077g01540, VIT_05s0077g01550,VIT_05s0077g01560, VIT_05s0077g01600, VIT_05s0077g01690, and VIT_01s0011g05150). PR-12 (defensin-like) were also observed (VIT_19s0085g00610). We also observed the up-regulation of a hypothetical endo-1,3(4)- $\beta$-glucanase 2 gene (VIT_14s0083g00340) (Cluster 6, Figure 5).

A set of PDR transporters genes (e.g., VIT_09s0002g05530,VIT_09s0002g05560,VIT_09s0002g05570, and VIT_09s0002g05590) that are responsible for the transportation of molecules through the membrane in response to stress were also induced.

Among the activation of defense mechanisms induced by infection, genes encoding GTS (e.g., VIT_08s0040g00920, VIT_05s0049g01090, and VIT_05s0049g01100, which are involved in multiple disease resistance) and cytochrome P450 (e.g., VITISV_011074, involved in oxidation of the plant hormone jasmonoyl-L-isoleucine; VITISV_033534, involved in ginsenoside biosynthesis; VIT_03s0063g01480, involved in methoxsalen biosynthesis; VIT_07s0141g00890 involved in catalysis of various fatty acids) were also observed to be up-regulated.

\subsection{DEGs Involved in ET and JA Biosynthesis and $\mathrm{Ca}^{2+}$ Signaling in the Inoculated Green Shoots}

Several DEGs encoding Ethylene/Jasmonic acid (ET/JA) signaling pathways such as genes related to phytoalexin biosynthesis, such as PAL (e.g., VIT_16s0039g01100, VIT_16s0039g01110, VIT_16s0039g01130, VIT_16s0039g01170, VIT_16s0039g01240, VIT_00s2849g00010, VIT_13s0019g04460, and VIT_06s0004g02620), STS (e.g., VIT_16s0100g00750, GSVIVT00007357001, VIT_16s0100g00920, VIT_16s0100g00830, VIT_16s0100g00850, VITISV_020801, VIT_16s0100g00880, VIT_16s0100g00900, GSVIVT00004047001, VIT_16s0100g01000, VIT_16s0100g01020, VIT_16s0100g01040, VITISV_026018, VIT_16s0100g01120, RS2, VIT_16s0100g01140, VIT_16s0100g01150, and VIT_16s0100g01170) and CHS (e.g., CHI1, CHS, CHS3, and VIT_14s0068g00920) were identified. The expression data showed that the genes involved in ET/JA biosynthesis were rapidly induced upon infection (e.g., Clusters 3 and 6, Figure 5).

Genes related to calcium $\left(\mathrm{Ca}^{2+}\right)$ signaling, such as genes related to $\mathrm{Ca}^{2+}$-dependent protein kinases (CDPKs), were identified (VIT_08s0032g01220). In addition, we identified genes encoding leucine-rich repeat (LRR) receptor-like kinases (RLKs) up- and down-regulated. These receptors with receptor-like serine/threonine-protein kinases (STKs) belong to the pattern recognition receptors (PRRs) family (e.g., VIT_19s0014g04130,VIT_17s0000g06710,VIT_07s0104g00850,VIT_00s0220g00120,VIT_07s0129g00960, VIT_08s0058g00540,VIT_08s0056g00150,VIT_08s0058g01340,VIT_08s0040g00060,VIT_10s0003g00330, VIT_10s0003g05160,VIT_11s0016g05720,VIT_12s0035g02090, and VIT_14s0128g00160). The activation of PRRs is the first step to initiate the innate immune mitogen-activated protein (MAP) kinase signaling cascade, resulting in enhanced resistance against pathogens [31]. A decrease in the expression through time of the VIT_17s0000g01970 gene (uncharacterized protein with MAP kinase activity) was observed (Cluster 3, Figure 5). Genes encoding NADPH oxidases respiratory burst oxidase homologs (Rboh) were also activated (VIT_11s0016g00540, VIT_02s0025g00510, and VIT_14s0060g02320).

Calmodulin/Calmodulin-like (CaM/CML) transcripts were also identified (e.g., VIT_08s0056g00290, VIT_01s0010g02930, VIT_01s0010g02940, VIT_01s0010g02950, VIT_01s0010g02970, VIT_01s0010g03040, VIT_01s0010g03000, VITISV_011291，VITISV_011291，VIT_14s0171g00150, VIT_18s0122g00180, VIT_18s0001g01630, VITISV_006244, VITISV_041123, VIT_05s0102g00450, and VIT_06s0080g00450). Genes of the WRKY family transcription factor, which play a key role in the 
regulation of disease resistance, were also represented in this set of signaling genes (VIT_08s0058g00690 and VIT_06s0004g07500).

\subsection{Predominant GO Functions of L. theobromae DEGs in the Time Series Analysis}

Seven hundred and six genes were differentially expressed in the time series analysis of $L$. theobromae. The functions of these temporal DEGs over time, based on GO analysis, are listed in Table S5. The best represented functions are related to processes involved in oxidation reduction $(17 \%)$, metabolism $(7 \%)$, transmembrane transport (6\%), carbohydrate (4\%), and proteolysis (4\%) (Figure 6). Fifteen of the 706 temporal DEGs in the time series analysis of the L. theobromae genes were fitted with a regression model with an $\mathrm{R}^{2}>0.8$ and were used for cluster analysis. Four clusters were defined (Figure 7 and Table S6). Each cluster contains genes that have similar expression profiles following the same trend over time. Clusters 1 and 4 (with six and two genes, respectively) show an increase in gene expression over time. These genes are mainly related to fungal development. Clusters 2 and 3 include six and one genes, respectively, and their expression decreases throughout time.

Twenty genes encoding cell wall-degrading enzymes (CWDEs) were identified differentially expressed in the transcriptome of L. theobromae: pectinases such as pectate lyases (BK809_0005263, BK809_0000650,BKCO1_1000601, and UCDDS831_g08741) and glycoside hydrolases (GHs) families 1, 2, 5, 10, 28, 29, 42, 43, 61, and 79 (e.g., BKCO1_6100046, BKCO1_940007, BKCO1_1000349, BKCO1_1000574, BKCO1_1800061, BKCO1_2800065, UCDDS831_g08450, MPH_05314, MPH_03522, MPH_08407, and BKCO1_2500059). Genes encoding a polygalacturonase (BK809_0000362), xylanases (UCRNP2_6170, UCRNP2_4063), and a pectinesterase (UCRNP2_4383) were also identified in the L. theobromae dataset and have been associated with pectin degradation. Several genes involved in the secondary metabolism such as cytochrome $\mathrm{P} 450$ genes were well represented in the transcriptome of L. theobromae (e.g., UCRNP2_7215, BKCO1_16000171, BKCO1_9000170,UCRNP2_1268, BKCO1_8400022, UCDDS831_g08095, BKCO1_1000650， BKCO1_27000127， BKCO1_4700086， BKCO1_3800026, UCRNP2_9053, UCDDS831_g00212, UCDDS831_g09295, UCDDS831_g08717, UCDDS831_g02163, and UCDDS831_g02126). Genes encoding monooxygenase FAD (Flavin Adenine Dinucleotide)-binding protein (MPH_09501) and berberine family protein (BKCO1_37000166) were also identified (Cluster 2, Figure 7). Genes related to the hydrolysis of sulfates, such as arylsulfatases (UCDDS831_g03540) were also identified (Cluster 1, Figure 7). Moreover, genes encoding salicylate hydroxylase (BKCO1_3300092), tyrosinase, (homo)gentisate dioxygenase (HGD), and fumarylacetoacetate hydrolases (FMH) (BKCO1_200014,UCDDS831_g07786, BKCO1_400034,UCRNP2_10214, and UCRNP2_9412), which are responsible for the degradation of salicylic acid and tyrosine/phenylalanine, were also found to be differentially expressed. In addition, genes encoding Nudix proteins were observed (BKCO1_4500094 and UCDDS831_g04159). 


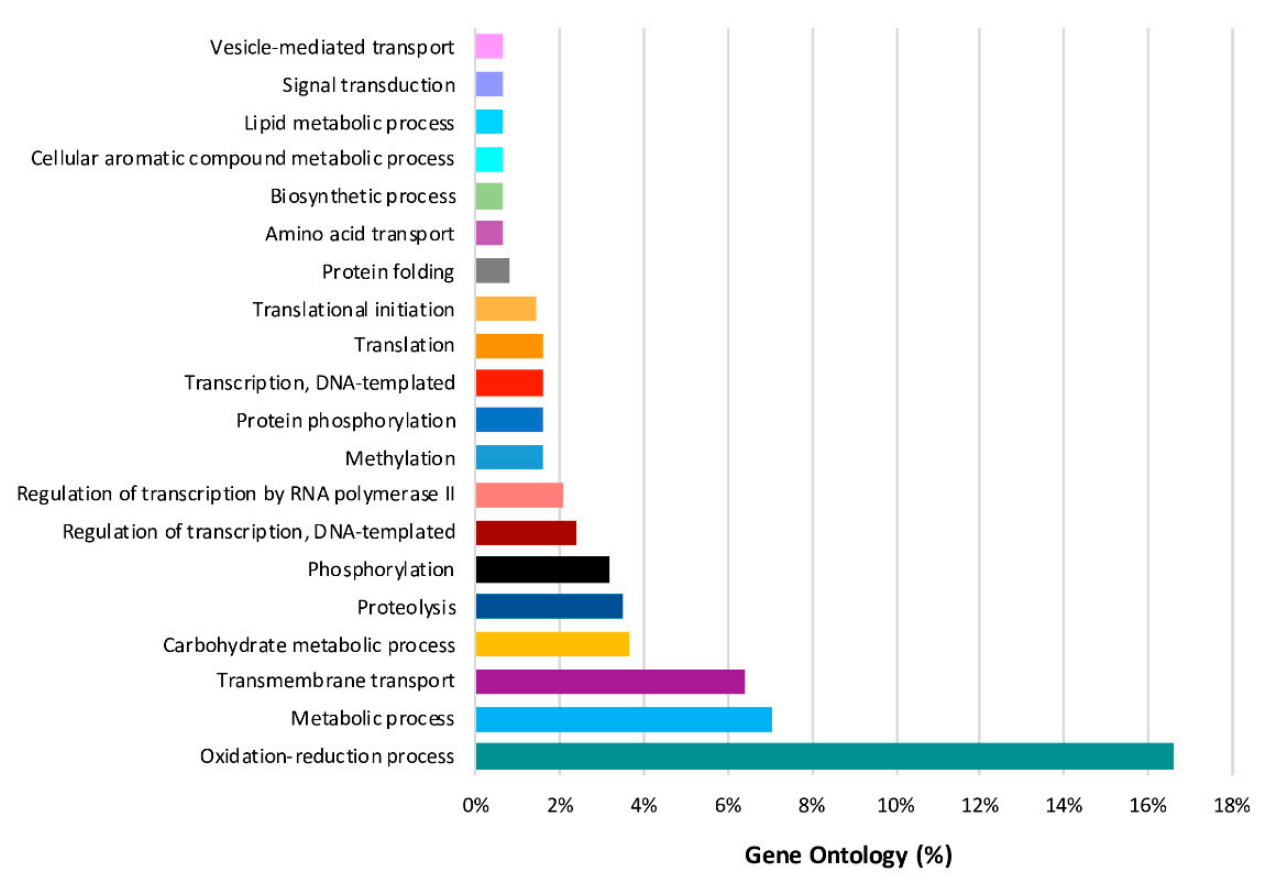

Figure 6. Gene Ontology terms (biological process) of the differentially expressed genes of L. theobromae over time.
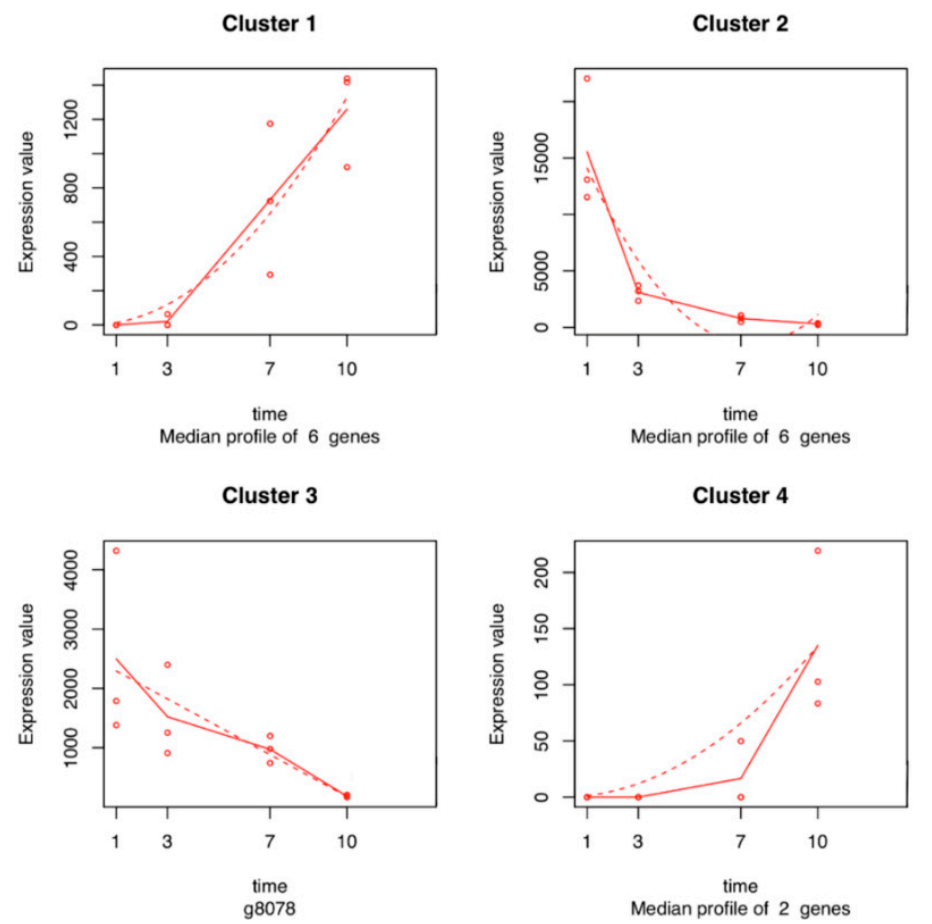

Figure 7. Expression profiles of L. theobromae gene clusters sharing a similar expression pattern during the colonization of grapevine stems. In each graph, the dots show the median expression value (i.e., normalized count) of all the genes in the cluster for each biological replicate at each time point. The solid lines represent the median of these median expression values at each time point. Dashed lines represent the fitted regression model that was performed on each cluster, modeling the relationship between median expression values of the cluster and the time points. 


\section{Discussion}

One-year-old plants of $V$. vinifera were inoculated with L. theobromae Bt105, and the progression of the lesion throughout the sampling points suggested that a successful infection occurred (Figure 1). For a better understanding of this host-pathogen interaction, a dual RNA-Seq approach, as described previously for other plant-pathogen systems [21,24], was performed to simultaneously detect pathogen and host responses.

As expected, pectinases such as pectate lyases, which are involved in pectin cleavage [32] and GHs, as well as glycosidic bonds breakdown in oligo- or polysaccharides including cellulose and hemicellulose [33], were among the pathways activated in L. theobromae. As reported previously, Botryosphaeria spp. and particularly L. theobromae [14,34,35] can degrade lignocellulose (laccases, cellulases, pectinases, and xylanases), which enable them to penetrate the host plant. Pectin is the main component of the middle lamella of plant tissues and therefore has a fundamental role blocking intercellular fungal development. Pectin degradation seems to be important for fungal pathogenicity. It has been described that pectin-degrading enzymes are the most abundant plant cell wall modifying proteins expressed during infection in grapevines by fungi that cause grapevine trunk diseases (e.g., Diplodia seriata, Neofusicoccum parvum, and Eutypa lata) [36].

After the successful penetration of the fungus inside the host, the pathogen needs to control the stress originated by the new environment and overcome host's defenses. Several genes related to secondary metabolism such as the cytochrome P450 monooxygenases superfamily, flavin-containing monooxygenases, and berberine enzymes-coding genes were identified. P450 monooxygenases are essential for fungal defense against antimicrobial substances produced by the hosts, which are involved in the production of mycotoxins, as aflatoxins and gibberellins, facilitating fungal adaptation to different niches $[37,38]$. Flavin-containing monooxygenases are microsomal proteins involved in the process of xenobiotics' metabolism [39]. Berberine enzymes form a subgroup of the superfamily of FAD-linked oxidases, and in fungi, they are known to be associated with oligosaccharide oxidation that originates from the breakdown of the cell wall components [40]. We observed a decrease in the gene expression of $L$. theobromae berberine enzymes throughout the infection time (Cluster 2, Figure 7), suggesting that $L$. theobromae focuses its initial efforts in the degradation of toxic compounds produced by the plant and the degradation of the plant cell wall. On the other hand, the increase in gene expression of arylsulfatases may suggest that $L$. theobromae uses sulfur as an alternative strategy to fungal development during host penetration. Arylsulfatase plays an important role in the cycle of sulfur, allowing the development of microorganisms in hostile environments [41]. Moreover, the expression of genes encoding salicylate hydroxylase, tyrosinase, HGD, and FMH support the observations of Paolinelli et al. [42], who showed that in the presence of the host (grapevine), L. theobromae strain UCD256Ma has the ability to degrade salicylic acid and phenylpropanoid pathway precursors, which are produced by the plant host as defense mechanisms.

The biological role of genes of Nudix proteins is poorly understood, but some studies demonstrate that these effectors are capable of manipulating the host defense, leading to an increase of the plant susceptibility and contributing to the virulence of the fungus [43]. Several proteins related with Nudix proteins were also identified in the transcriptome and proteome of L. theobromae LA-SOL 3 at $25^{\circ} \mathrm{C}$ and $37^{\circ} \mathrm{C}$ as having relevant functions for pathogenicity [44].

The most abundant functions of $V$. vinifera DEGs inoculated with $L$. theobromae were indicative of a host actively trying to combat infection (Figure 3; Figure 4). We observed the differential expression of many genes related to defense responses related to infection processes. When a grapevine is under fungal attack, it activates inducible defense mechanisms to effectively combat the invasion $[45,46]$. One of the inducible plant defense responses is the synthesis and secretion of PR proteins, which are known as being part of systemic acquired resistance. Most PR proteins have antimicrobial activities and toxicity toward pathogen cell walls. PR proteins can also be involved in plant defense signaling [47]. We identified many up-regulated PR-transcripts in infected plants. PR-3 and PR-4 are involved in the degradation of fungal cell walls, and PR-5 are involved in antifungal and membrane-permeabilizing 
activity [48]. Jayasankar et al. [49] showed that the inhibition of spore germination and hyphal growth of the fungal pathogen Elsinoe ampelina involves grapevine's PR-5 (VvTLP-1). The antifungal activity of grapevine's TLPs on the growth of Diaporthe ampelina and Botrytis cinerea mycelia was confirmed by Monteiro et al. [50]. The up-regulation of a hypothetical endo-1,3(4)- $\beta$-glucanase 2 coding gene (Cluster 6, Figure 5) might be related with PR-5. In fact, it has been reported that the functions of PR-5 and PR-2 against pathogenic microorganisms are related in some cases to endo- $\beta$-1,3-glucanase activity [51]. Derckel et al. [52] observed the up-regulation of PR-2 and accumulation of $\beta-1,3$-glucanase in grapevines during infection with $B$. cinerea. Moreover, we identified many genes encoding PR-10-related proteins in the $V$. vinifera transcriptome, which may also suggest a role in the defense against L. theobromae. As reported by Dadakova et al. [53] on V. vinifera cell's suspension inoculated with B. cinerea, PR-10 proteins cause the inhibition of hyphal growth and the reduction of spore germination through membrane permeabilization mechanisms and interact with pathogen receptors. Lastly, Giacomelli et al. [54] also reported the expression of PR-12 transcripts in grape tissues infected with B. cinerea, suggesting a role in the defense. As reported for other Botryosphaeriaceae species, such as N. parvum, L. viticola, Diplodia mutila, and D. seriata [55], the expression of genes coding for PR proteins in grapevine is significantly intense within a short term after the first contact with pathogens.

Phytoalexin biosynthesis genes, such as PAL, STS, and CHS, were among the transcripts activated in the stem upon L. theobromae infection, suggesting that they could play a role in defense signaling. Infection of V. vinifera by B. cinerea activates the JA/ET pathway and induces genes related to phytoalexin biosynthesis. Phytoalexins are involved in the reduction of spore germination and inhibition of the fungus penetration $[45,56,57]$. Phenylalanine ammonia-lyases are key enzymes of phenylpropanoids metabolism. These enzymes are important in plant development and serve as markers for induced resistance in plants [58]. Stilbene synthases and CHS are members of the plant polyketide synthase superfamily, which is also involved in the signaling of defence responses and antifungal compounds production $[59,60]$. In grapevines with Botryosphaeria dieback, the induction and accumulation of stilbene compounds after 2 dpi was reported in V. vinifera cv. "Cabernet Sauvignon", "Merlot", "Ugni-Blanc", and "RV4 hybrid" one-year-old plants ${ }^{54}$. Similar observations in one-year-old V. vinifera cv. "Cabernet Sauvignon" clone 19 in response to N. parvum infection were reported by Massonnet et al. [24] at $1 \mathrm{dpi}$. The expression data showed that the genes involved in JA biosynthesis were rapidly induced upon infection with $L$. theobromae (e.g., Clusters 3 and 6, Figure 5). Similar results were observed in peach trees (Prunus persica L.) inoculated with L. theobromae [27] and in Arabidopsis thaliana infected with B. cinereal $[61,62]$.

Overall, our data demonstrated that distinct components of the phenylpropanoid pathway were activated, suggesting that when L. theobromae infects unstressed grapevines, it also selectively degrades pectin, which allows it to grow in intercellular spaces. Lasiodiplodia theobromae's presence seems to trigger the host defensive mechanisms mediated by the activation of the phenylpropanoid pathway. However, host defense can be impaired by the activity of fungal phenylpropanoid precursors. On the other hand, some authors suggest that in the presence of the pathogen, the host defensive mechanism could be mediated through salicylic acid, and the plant defenses could be impaired by the activity of salicylic acid precursors [42]. Thus, variations of grapevine genotypes in relation to their resistance to infection, degree of fungal colonization, and severity of disease could be linked with this defense strategy.

In addition, genes related to $\mathrm{Ca}^{2+}$ signaling pathways were also activated, which is indicative of defense signaling. $\mathrm{Ca}^{2+}$-dependent protein kinases are triggered by pathogen-associated molecular patterns (PAMPs) via PRRs through changes in $\mathrm{Ca}^{2+}$ concentration within the cell. After $\mathrm{Ca}^{2+}$ signaling, $\mathrm{Ca}^{2+}$-dependent protein kinases activate Rboh through $\mathrm{Ca}^{2+}$ increase in the cytoplasm, $\mathrm{Ca}^{2+}$ binding, and phosphorylation [63]. The activation of Rboh induces reactive oxygen species (ROS), which trigger a hypersensitive response (HR) and cell wall reinforcement [64,65]. In addition, the activation of CDPK by intracellular effector proteins will trigger the biosynthesis of SA, JA, and ET through regulatory gene induction or enzyme activation such as the phenylalanine ammonia lyase mentioned above. Recent 
studies showed the involvement of CaM/CML-related genes in the induction of HR, suggesting their importance in plant immunity [66]. In plant cells, CaM/CML interacts with transcription factors such as WRKYs that we also observed. Massonnet et al. [24] reported the expression of genes related to the $\mathrm{Ca}^{2+}$ signaling and WRKY family transcription factor that were shown to be involved in grape resistance against necrotrophic fungal pathogens and in the regulation of lignin deposition $[67,68]$.

In a recent study, the transcriptional responses of green shoots from grapevine cultivar 'Summer Black' infected with $L$. theobromae over 4,8 , and $12 \mathrm{~h}$ post-inoculation (hpi) were analyzed [23]. It is known that there is a broad range of variability in the aggressiveness of different isolates of $L$. theobromae against grapevines [1]. In fact, the L. theobromae strain used by Zhang et al. [23] successfully infected grapevine green shoots and produced visible lesions within $24 \mathrm{hpi}$. However, in our study at $1 \mathrm{dpi}$, there were no visible lesions produced by the L. theobromae strain used. In agreement with the lack of visual symptoms, at $1 \mathrm{dpi}$, we did not observe DEGs, which may be related to the different aggressiveness of both strains. Nonetheless, using a different cultivar and a different fungal strain, along with a longer time course (up to $10 \mathrm{dpi}$ ), our observations corroborate those of Zhang et al. [23], namely in what concerns hormone signal transduction and phenylpropanoid biosynthesis pathways. Both studies contribute with an in-depth view of the molecular interactions between grapevine and L. theobromae over time. In addition, we identify potential mechanisms used by L. theobromae during infection and establishment in the host.

\section{Materials and Methods}

\subsection{Biological Material and Experimental Design}

The experiment was conducted on 1-year-old grafted grapevine cuttings cultivar "Touriga Nacional" (rootstock 1103 Paulsen), which were propagated in $10 \times 10 \mathrm{~cm}$ pots 2 months before inoculation, as described by Travadon et al. [69]. Lasiodiplodia theobromae strain Bt105 (isolated from V. vinifera cv. Castelão in Portugal) was grown on potato dextrose agar (PDA) (Merck, Germany) at $25^{\circ} \mathrm{C}$ for 5 days prior to inoculation. In total, 24 plants were arranged in a randomized design in a greenhouse. Grapevines were subjected to two different treatments: inoculated and "mock" inoculated plants (control). The time of experiment was 10 days and samples were collected at 1, 3, 7, and 10 days post-inoculation (dpi). Sampling points were selected based on preliminary observations of plant symptoms, namely necrosis development and progression. Three biological replicates per treatment and per sampling point were used. Plants were disinfected with $96 \%$ ethanol between the second and third internode and cut with a cork borer; then, a colonized agar disc $(4 \mathrm{~mm})$ was placed on the wound, which was then covered with water-soaked cotton and sealed with Parafilm. Control plants were inoculated with discs of non-colonized PDA medium.

\subsection{Sample collection}

Green shoots $(\mathrm{n}=3)$ were collected for each treatment for each sampling point. Three $\mathrm{cm}^{2}$ of stem tissue was harvested per inoculation site ( $1.5 \mathrm{~cm}$ of stem tissue below and above the inoculation site). Harvested material was immediately frozen in liquid nitrogen and subsequently stored at $-80^{\circ} \mathrm{C}$ for RNA extraction. Photographs were taken during the experiment, and the progression of the necrosis was monitored.

\subsection{RNA Extraction, Library Preparation, and Sequencing}

Stem tissue samples $(n=24)$ were ground in liquid nitrogen, and the total RNA was extracted using cetyltrimethyl ammonium bromide (CTAB)-based extraction protocol according to Gambino et al. [70] followed by a DNase I treatment (RNase-Free DNase Set, Qiagen). The concentration and quality of the total extracted RNA were checked using the 'Quant-it ribogreen RNA assay' (Life Technologies, Grand Island, NY, USA) and the RNA 6000 nano chip (Agilent Technologies, Santa Clara, CA, USA), respectively. Afterward, samples were stored at $-80^{\circ} \mathrm{C}$ until sequencing library preparation. Illumina 
mRNA sequencing libraries were made from $200 \mathrm{ng}$ of total RNA of each sample using the QuantSeq $3^{\prime}$ mRNA-Seq Library Prep Kit (Lexogen, Vienna, Austria) according to manufacturer's protocol using 15 cycles for the enrichment PCR step. Libraries were quantified by qPCR on a Lightcycler 480 (Roche, Basel, Switzerland), according to Illumina's protocol 'Sequencing Library qPCR Quantification protocol guide', version February 2011. A high-sensitivity DNA chip (Agilent Technologies, Santa Clara, CA, USA) was used to control the library's size distribution and quality. The libraries were equimolarly pooled and sequenced at the NXTGNT facility (www.nxtgnt.ugent.be, Ghent University) on an Illumina NextSeq 500 sequencer controlled by NextSeq Control Software (NCS 2.1.2) using a High Output Kit v2 (75 Cycles), generating single-end 75 bp reads.

Per sample $(n=24)$, on average, $20.5 \pm 4.7$ million reads were generated. Adequate sequencing quality was confirmed using FastQC version 0.11.5 [71]. Afterwards, these reads were trimmed using Cutadapt [72] version 1.11 to remove the "QuantSEQ FWD" adaptor sequence. Potential contamination was checked using FastQ Screen version 0.7.0 [73]. The trimmed reads were mapped to the combined annotated reference genome of $V$. vinifera (NCBI Reference Sequence: GCF_000003745.3) and L. theobromae strain LA-SOL3 (SAMN08892999, [44]) using the STAR aligning software version 2.5.3a [74]. Following the mapping step, the RSEM software version v1.2.31 [75] was used to generate the count tables for both $V$. vinifera and L. theobromae. Two samples of control plants collected at time point $3 \mathrm{~d}$ pi were removed after the detection of L. theobromae contamination. Sequencing and mapping quality reports were aggregated with MultiQC version 1.0 [76]. Raw reads and raw count data are accessible in the Gene Expression Omnibus (GSE129109).

\subsection{Pairwise Comparison of the Samples Based on V. vinifera Genes}

For each time point, differential gene expression analysis was done between the samples of the "mock" inoculated plants as the control group and the samples from the inoculated plants as the treatment group using edgeR [77] performing the following steps. First, read counts were normalized using the standard edgeR [77] normalization method. Only genes with a count per million (cpm) $>1$ in at least three samples were considered for statistical differential gene expression analysis. Subsequently, a general linear model was built, and statistical testing was done using the empirical Bayes quasi-likelihood F-test. Computed $p$-values were adjusted using the Benjamin-Hochberg false discovery rate (FDR) correction to account for multiple comparisons. Genes having an FDR $<0.01$ and a $\log _{2}$ fold change $(\mathrm{FC})>1$ or $<-1$ were considered significantly differentially expressed. To understand the functions of the differentially expressed genes (DEGs), a Gene Ontology (GO) analysis was performed using the GOslim software. The significant enrichment of GO terms based on hypergeometric distribution followed by FDR $<0.05$ correction was used for comparison between the test set and reference set of each species using ShinyGO v0.61 (http://bioinformatics.sdstate.edu/go/).

\subsection{Time Series Analysis}

In addition to the pairwise comparisons, a time series analysis with the maSigPro R package [78] was performed. Read counts of $V$. vinifera were normalized using the standard edgeR [77] normalization method. Only genes with a count per million (cpm) $>1$ in at least three samples were considered for the time series analysis. A full general linear model with all these genes, all conditions (treatment and control), and with a linear and quadratic time factor was fitted to the data. Differential expression analysis was performed whereby genes were significantly differentially expressed if one or more conditions/factors have a significant contribution to the fitted model using an FDR $<0.05$. For each of these temporal DEGs, a stepwise regression was performed modeling the relationship between expression and the time points, whereby the inclusion or exclusion of the quadratic time factor was decided based on a $p$-value of 0.05 . Genes with a regression model with an $R^{2}>0.8$ were further used in a Ward's hierarchical clustering analysis. In the clustering analysis, genes with a similar expression profile (i.e., a similar regression model) were clustered together. 
In addition, for the $L$. theobromae genes, a time series analysis was performed as described above. Thereby, a full general linear model with only a linear and quadratic time factor was fitted to the data.

\section{Conclusions}

The outcomes of this study provide the first report that assess both host and pathogen transcriptomes simultaneously, detecting L. theobromae-specific transcripts in the same sample, such as genes related to phenolic compounds, carbohydrate metabolism, transmembrane transport, and toxin synthesis. In addition, genes encoding for the degradation of plant phenylpropanoid precursors such as salicylate hydroxylase, tyrosinase, (homo)gentisate dioxygenase, and fumarylacetoacetate hydrolases were detected, suggesting that $L$. theobromae could evade the host defense response using the phenylpropanoid pathway. Additionally, our results corroborate other studies focused on grapevine transcriptome when inoculated with L. theobromae as genes related to phytoalexin biosynthesis, hormone metabolism, cell wall modification enzymes, many pathogenesis-related proteins, and phenylpropanoid compounds involved in the host responses to infection. An integrated overview of the most frequent responses detected is summarized in Figure 8 (inspired on the model of $V$. vinifera and the bacterium Xylella fastidiosa interactions [79]). Comparative studies with other cultivar or pathogen strains differing in susceptibility and aggressiveness might give a crucial complement to understand the plant resistance/susceptibility to infections. Moreover, further studies focused on systemic acquired resistance and induced systemic resistance ("priming") are necessary to understand the mechanisms of fast, strong, and effective defense responses after pathogen challenge.

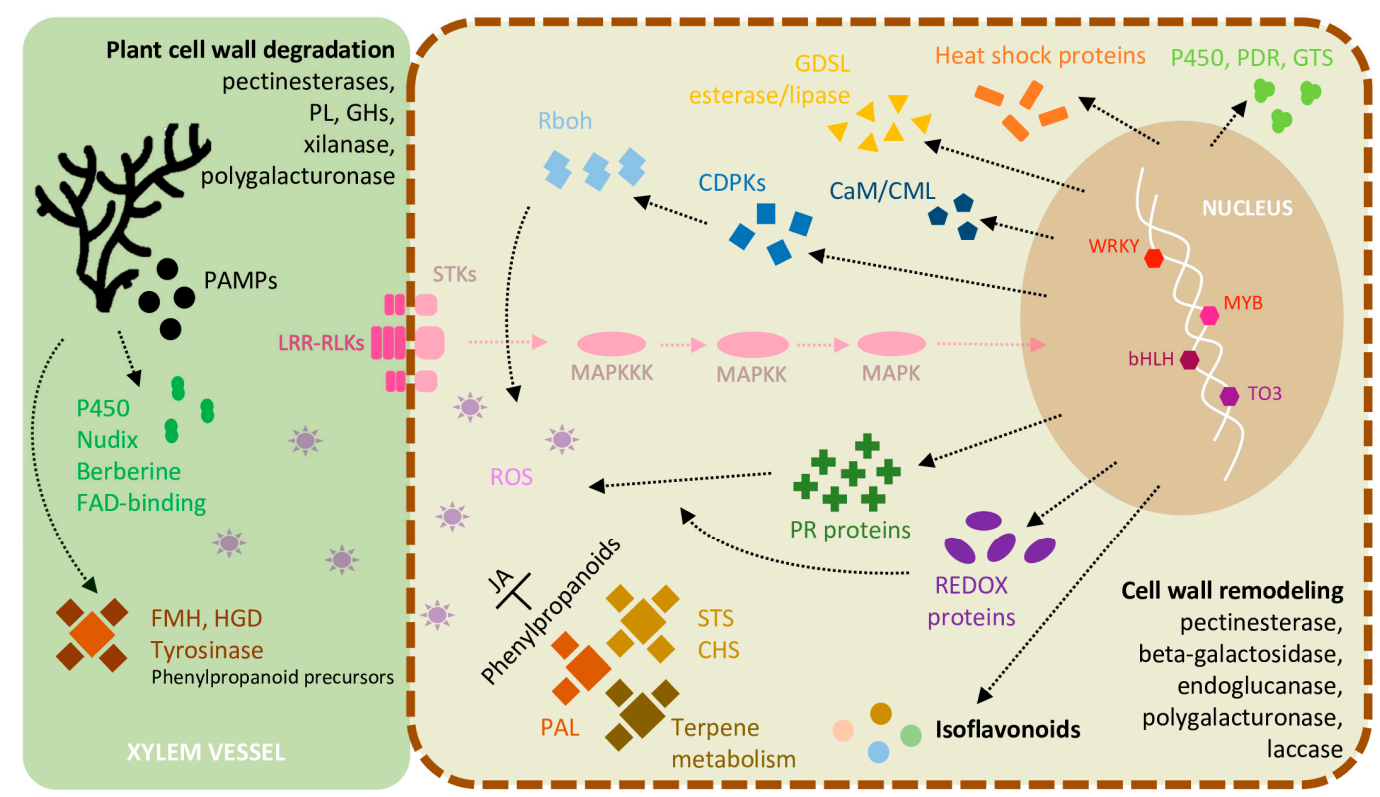

Figure 8. Model illustrating the most frequent molecular events occurring in $V$. vinifera infected with L. theobromae. Transcriptomic analyses highlight the ability of L. theobromae to degrade cell wall components and to control host defences. The perception of the fungus by grapevine trigger many inducible defence mechanisms, signaling cascades, and stress response. PL: pectate lyase; GHs: glycoside hydrolases; PAMPs: pathogen=associated molecular patterns; LRR-RLKs: leucine-rich repeat receptor-like kinases; STKs: receptor-like serine/threonine-protein kinases; MAPKs: mitogen-activated protein kinases; FMH: fumarylacetoacetate hydrolase; HGD: (homo)gentisate dioxygenase; Rboh: NADPH oxidases respiratory burst oxidase homologs; CDPKs: $\mathrm{Ca}^{2+}$-dependent protein kinases; CaM/CML: Calmodulin/Calmodulin-like proteins; PDR: pleiotropic drug resistance; GTS: glutathione transferase; PR proteins: pathogenesis-related proteins; JA: jasmonic acid; STS: stilbene synthase; CHS: chalcone synthase; PAL: phenylalanine ammonia lyase; Transcription factors: WRKY, MYB, bHLH, TO3. 
Supplementary Materials: Supplementary Materials can be found at http:/www.mdpi.com/1422-0067/20/23/ 6083/s1. Figure S1: Saturation curves of V. vinifera genes, Figure S2: Saturation curves of L. theobromae genes, Table S1: Gene Ontologies of DEG's in response to L. theobromae inoculation in V. vinifera at 3 dpi, Table S2: Gene Ontologies of DEG's in response to L. theobromae inoculation in V. vinifera at 7 dpi, Table S3: Gene Ontologies of DEG's in response to L. theobromae inoculation in $V$. vinifera at $10 \mathrm{dpi}$, Table S4: Significantly enriched GO terms identified from differentially expressed $V$. vinifera genes, Table S5: Gene clusters of DEG's of $V$. vinifera with a regression model with an $\mathrm{R}_{2}>0.8$ during the colonization of grape stems, Table S6: Gene Ontologies of DEG's of L. theobromae over time, Table S7: Gene clusters of DEG's of L. theobromae with a regression model with an $R_{2}>0.8$ during the infection of grape stems.

Author Contributions: A.A. and A.C.E. designed the research. M.F.M.G. and F.V.N. performed the experiment. M.F.M.G., R.B.N. and L.T. performed the data analysis and interpretation. M.F.M.G. and R.B.N. wrote the paper. A.A., A.C.E., Y.V.d.P., D.D. and F.V.N. edited and approved the manuscript. All authors read and approved the final manuscript.

Funding: This research was funded by European funds through COMPETE and by national funds through the Portuguese Foundation for Science and Technology (FCT) within project ALIEN (PTDC/AGR-PRO/2183/2014 POCI-01-0145-FEDER-016788) and PhD grant for M. Gonçalves (SFRH/BD/129020/2017). Thanks are also due to FCT and UCP for the CEEC institutional financing of AC Esteves.

Acknowledgments: We thank Cecília Rego at the Superior Institute of Agronomy (ISA), University of Lisbon and Andreia Cerqueira for her contributions to experimental procedures in the greenhouse.

Conflicts of Interest: The authors declare no competing financial interests.

$\begin{array}{ll}\text { Abbreviations } \\ \text { dpi } & \text { Days post-inoculation } \\ \text { hpi } & \text { Hours post-inoculation } \\ \text { GO } & \text { Gene Ontology } \\ \text { DEGs } & \text { Differentially expressed genes } \\ \text { PR } & \text { Pathogenesis related } \\ \text { PRRs } & \text { Pattern recognition receptors } \\ \text { GSTs } & \text { Glutathione transferases } \\ \text { PDR } & \text { Pleiotropic drug resistance } \\ \text { TLPs } & \text { Thaumatin-like proteins } \\ \text { STS } & \text { Stilbene synthase } \\ \text { CHS } & \text { Chalcone synthase } \\ \text { PAL } & \text { Phenylalanine ammonia lyase } \\ \text { ET/JA } & \text { Ethylene/Jasmonic acid } \\ \text { CDPKs } & \text { Ca2+-dependent protein kinases } \\ \text { FAD } & \text { Flavin adenine dinucleotide } \\ \text { CaM/CML } & \text { Calmodulin/Calmodulin-like transcripts } \\ \text { CTAB } & \text { Cetyltrimethyl ammonium bromide }\end{array}$

\section{References}

1. Úrbez-Torres, J.R.; Gubler, W.D. Pathogenicity of Botryosphaeriaceae species isolated from grapevine cankers in California. Plant Dis. 2009, 93, 584-592. [CrossRef] [PubMed]

2. Úrbez-Torres, J.R. The status of Botryosphaeriaceae species infecting grapevines. Phytopathol. Mediterr. 2011, 50, 5-45.

3. Bertsch, C.; Ramírez-Suero, M.; Magnin-Robert, M.; Larignon, P.; Chong, J.; Abou-Mansour, E.; Spagnolo, A.; Clément, C.; Fontaine, F. Grapevine trunk diseases: Complex and still poorly understood. Plant Pathol. 2013, 62, 243-265. [CrossRef]

4. Kaplan, J.; Travadon, R.; Cooper, M.; Hillis, V.; Lubell, M.; Baumgartner, K. Identifying economic hurdles to early adoption of preventative practices: The case of trunk diseases in California winegrape vineyards. Wine Econ. Pol. 2016, 5, 127-141. [CrossRef]

5. Slippers, B.; Wingfield, M.J. Botryosphaeriaceae as endophytes and latent pathogens of woody plants: Diversity, ecology and impact. Fungal Biol. Rev. 2007, 21, 90-106. [CrossRef]

6. Eastburn, D.M.; McElrone, A.J.; Bilgin, D.D. Influence of atmospheric and climatic change on plant-pathogen interactions. Plant Pathol. 2011, 60, 54-69. [CrossRef] 
7. Gallana, M.; Ryser-Degiorgis, M.P.; Wahli, T.; Segner, H. Climate change and infectious diseases of wildlife: Altered interactions between pathogens, vectors and hosts. Curr. Zool. 2013, 59, 427-437. [CrossRef]

8. $\quad$ King, B.C.; Waxman, K.D.; Nenni, N.V.; Walker, L.P.; Bergstrom, G.C.; Gibson, D.M. Arsenal of plant cell wall degrading enzymes reflects host preference among plant pathogenic fungi. Biotechnol. Biofuels 2011, 4, 4. [CrossRef]

9. Taylor, A.; Hardy, G.E.S.J.; Wood, P.; Burgess, T. Identification and pathogenicity of Botryosphaeria species associated with grapevine decline in Western Australia. Australas. Plant Pathol. 2005, 34, 187-195.

10. Úrbez-Torres, J.R.; Leavitt, G.M.; Guerrero, J.C.; Guevara, J.; Gubler, W.D. Identification and pathogenicity of Lasiodiplodia theobromae and Diplodia seriata, the causal agents of bot canker disease of grapevines in Mexico. Plant Dis. 2008, 92, 519-529. [CrossRef]

11. Rodríguez-Gálvez, E.; Maldonado, E.; Alves, A. Identification and pathogenicity of Lasiodiplodia theobromae causing dieback of table grapes in Peru. Eur. J. Plant Pathol. 2015, 141, 477-489. [CrossRef]

12. Alves, A.; Crous, P.W.; Correia, A.; Phillips, A.J.L. Morphological and molecular data reveal cryptic speciation in Lasiodiplodia theobromae. Fungal Divers. 2008, 28, 1-13.

13. Phillips, A.J.L.; Alves, A.; Abdollahzadeh, J.; Slippers, B.; Wingfield, M.J.; Groenewald, J.Z.; Crous, P.W. The Botryosphaeriaceae: Genera and species known from culture. Stud. Mycol. 2013, 76, 51-167. [CrossRef] [PubMed]

14. Félix, C.; Duarte, A.S.; Vitorino, R.; Guerreiro, A.C.; Domingues, P.; Correia, A.; Alves, A.; Esteves, A.C. Temperature modulates the secretome of the phytopathogenic fungus Lasiodiplodia theobromae. Front. Plant Sci. 2016, 7, 1096. [CrossRef]

15. Correia, K.; Câmara, M.P.S.; Barbosa, M.A.G.; Sales, R., Jr.; Agustí-Brisach, C.; Gramaje, D.; León, M.; Garcia-Jiménez, J.; Abad-Campos, P.; Armengol, J.; et al. Fungal trunk pathogens associated with table grape decline in Northeastern Brazil. Phytopathol. Mediterr. 2013, 52, 380-387.

16. Aroca, A.; Raposo, R.; Gramaje, D.; Armengol, J.; Martos, S.; Luque, J. First report of Lasiodiplodia theobromae associated with decline of grapevine rootstock mother plants in Spain. Plant Dis. 2008, 92, 832. [CrossRef]

17. Burruano, S.; Mondello, V.; Conigliaro, G.; Alfonzo, A.; Spagnolo, A.; Mugnai, L. Grapevine decline in Italy caused by Lasiodiplodia theobromae. Phytopathol. Mediterr. 2008, 47, 132-136.

18. Úrbez-Torres, J.R.; Leavitt, G.M.; Voegel, T.M.; Gubler, W.D. Identification and distribution of Botryosphaeria spp. associated with grapevine cankers in California. Plant Dis. 2006, 90, 1490-1503. [CrossRef]

19. Naidoo, S.; Visser, E.A.; Zwart, L.; Du Toit, Y.; Bhadauria, V.; Shuey, L.S. Dual RNA-seq to elucidate the plantpathogen duel. Curr. Issues Mol. Biol. 2017, 27, 127-142.

20. Dou, D.; Zhou, J.M. Phytopathogen effectors subverting host immunity: Different foes, similar battleground. Cell Host Microbe 2012, 12, 484-495. [CrossRef]

21. Meyer, F.E.; Shuey, L.S.; Naidoo, S.; Mamni, T.; Berger, D.K.; Myburg, A.A.; van den Berg, N.; Naidoo, S. Dual RNA-sequencing of Eucalyptus nitens during Phytophthora cinnamomi challenge reveals pathogen and host factors influencing compatibility. Front. Plant Sci. 2016, 7, 191. [CrossRef] [PubMed]

22. Westermann, A.J.; Gorski, S.A.; Vogel, J. Dual RNA-seq of pathogen and host. Nat. Rev. Microbiol. 2012, 10, 618. [CrossRef] [PubMed]

23. Zhang, W.; Yan, J.; Li, X.; Xing, Q.; Chethana, K.T.; Zhao, W. Transcriptional response of grapevine to infection with the fungal pathogen Lasiodiplodia theobromae. Sci. Rep. 2019, 9, 5387. [CrossRef] [PubMed]

24. Massonnet, M.; Figueroa-Balderas, R.; Galarneau, E.R.; Miki, S.; Lawrence, D.P.; Sun, Q.; Wallisc, C.M.; Baumgartner, K.; Cantu, D. Neofusicoccum parvum colonization of the grapevine woody stem triggers asynchronous host responses at the site of infection and in the leaves. Front. Plant Sci. 2017, 8, 1117. [CrossRef] [PubMed]

25. Lowe, R.G.T.; Cassin, A.; Grandaubert, J.; Clark, B.L.; Van de Wouw, A.P.; Rouxel, T.; Howlett, B.J. Genomes and transcriptomes of partners in plant- fungal- interactions between canola (Brassica napus) and two Leptosphaeria species. PLoS ONE 2014, 9, e103098. [CrossRef]

26. Yazawa, T.; Kawahigashi, H.; Matsumoto, T.; Mizuno, H. Simultaneous transcriptome analysis of sorghum and Bipolaris sorghicola by using RNA-seq in combination with de novo transcriptome assembly. PLoS ONE 2013, 8, e62460. [CrossRef] [PubMed]

27. Gao, L.; Wang, Y.; Li, Z.; Zhang, H.; Ye, J.; Li, G. Gene expression changes during the gummosis development of peach shoots in response to Lasiodiplodia theobromae infection using RNA-Seq. Front. Physiol. 2016, 7, 170. [CrossRef] 
28. Teixeira, P.J.; Thomazella, D.P.; Reis, O.; do Prado, P.F.V.; do Rio, M.C.S.; Fiorin, G.L.; José, J.; Costa, G.G.L.; Negri, V.A.; Mondego, J.M.C.; et al. High-resolution transcript profiling of the atypical biotrophic interaction between Theobroma cacao and the fungal pathogen Moniliophthora perniciosa. Plant Cell 2014, 26, 4245-4269. [CrossRef]

29. Enault, F.; Suhre, K.; Claverie, J.M. Phydbac "Gene Function Predictor": A gene annotation tool based on genomic context analysis. BMC Bioinform. 2005, 6, 247. [CrossRef]

30. Singh, H.; Rai, K.M.; Upadhyay, S.K.; Pant, P.; Verma, P.C.; Singh, A.P.; Singh, P.K. Transcriptome sequencing of a thalloid bryophyte; Dumortiera hirsuta (Sw) Nees: Assembly, annotation, and marker discovery. Sci. Rep. 2015, 5, 15350. [CrossRef]

31. Rasmussen, M.W.; Roux, M.; Petersen, M.; Mundy, J. MAP kinase cascades in Arabidopsis innate immunity. Front. Plant Sci. 2012, 3, 169. [CrossRef] [PubMed]

32. Reignault, P.; Valette-Collet, O.; Boccara, M. The importance of fungal pectinolytic enzymes in plant invasion, host adaptability and symptom type. Eur. J. Plant Pathol. 2008, 120, 1-11. [CrossRef]

33. Kubicek, C.P.; Starr, T.L.; Glass, N.L. Plant cell wall-degrading enzymes and their secretion in plant-pathogenic fungi. Annu. Rev. Phytopathol. 2014, 52, 427-451. [CrossRef] [PubMed]

34. Alves da Cunha, M.A.; Barbosa, A.M.; Giese, E.C.; Dekker, R.F. The effect of carbohydrate carbon sources on the production of constitutive and inducible laccases by Botryosphaeria sp. J. Basic Microbiol. 2003, 43, 385-392. [CrossRef]

35. Félix, C.; Libório, S.; Nunes, M.; Félix, R.; Duarte, A.; Alves, A.; Esteves, A. Lasiodiplodia theobromae as a producer of biotechnologically relevant enzymes. Int. J. Mol. Sci. 2018, 19, 29. [CrossRef]

36. Morales-Cruz, A.; Amrine, K.C.; Blanco-Ulate, B.; Lawrence, D.P.; Travadon, R.; Rolshausen, P.E.; Baumgartner, K.; Cantu, D. Distinctive expansion of gene families associated with plant cell wall degradation, secondary metabolism, and nutrient uptake in the genomes of grapevine trunk pathogens. BMC Genom. 2015, 16, 469. [CrossRef]

37. Črešnar, B.; Petrič, Š. Cytochrome P450 enzymes in the fungal kingdom. Biochim. Biophys. Acta 2011, 1814, 29-35. [CrossRef]

38. Nierman, W.C.; Pain, A.; Anderson, M.J.; Wortman, J.R.; Kim, H.S.; Arroyo, J.; Bennett, J.; Bowyer, P.; Chen, D.; Collins, M.; et al. Genomic sequence of the pathogenic and allergenic filamentous fungus Aspergillus fumigatus. Nature 2005, 438, 1151. [CrossRef]

39. Eswaramoorthy, S.; Bonanno, J.B.; Burley, S.K.; Swaminathan, S. Mechanism of action of a flavin-containing monooxygenase. Proc. Natl. Acad. Sci. USA 2006, 103, 9832-9837. [CrossRef]

40. Daniel, B.; Konrad, B.; Toplak, M.; Lahham, M.; Messenlehner, J.; Winkler, A.; Macheroux, P. The family of berberine bridge enzyme-like enzymes: A treasure-trove of oxidative reactions. Arch. Biochem. Biophys. 2017, 632, 88-103. [CrossRef]

41. Cregut, M.; Piutti, S.; Slezack-Deschaumes, S.; Benizri, E. Compartmentalization and regulation of arylsulfatase activities in Streptomyces sp., Microbacterium sp. and Rhodococcus sp. soil isolates in response to inorganic sulfate limitation. Microbiol. Res. 2013, 168, 12-21. [CrossRef] [PubMed]

42. Paolinelli-Alfonso, M.; Villalobos-Escobedo, J.M.; Rolshausen, P.; Herrera-Estrella, A.; Galindo-Sánchez, C.; López-Hernández, J.F.; Hernandez-Martinez, R. Global transcriptional analysis suggests Lasiodiplodia theobromae pathogenicity factors involved in modulation of grapevine defensive response. BMC Genom. 2016, 17, 615. [CrossRef] [PubMed]

43. Dong, S.; Wang, Y. Nudix Effectors: A common weapon in the arsenal of plant pathogens. PLoS Pathog. 2016, 12, e1005704. [CrossRef] [PubMed]

44. Félix, C.; Meneses, R.; Gonçalves, M.F.; Tilleman, L.; Duarte, A.S.; Jorrín-Novo, J.V.; Van de Peer, Y.; Deforce, D.; Van Nieuwerburgh, F.; Esteves, A.C.; et al. A multi-omics analysis of the grapevine pathogen Lasiodiplodia theobromae reveals that temperature affects the expression of virulence-and pathogenicity-related genes. Sci. Rep. 2019, 9, 1-12. [CrossRef]

45. Chong, J.; Le Henanff, G.; Bertsch, C.; Walter, B. Identification, expression analysis and characterization of defense and signaling genes in Vitis vinifera. Plant Physiol. Biochem. 2008, 46, 469-481. [CrossRef]

46. Armijo, G.; Schlechter, R.; Agurto, M.; Muñoz, D.; Nuñez, C.; Arce-Johnson, P. Grapevine pathogenic microorganisms: Understanding infection strategies and host response scenarios. Front. Plant Sci. 2016, 7, 382. [CrossRef] 
47. Van Loon, L.C.; Rep, M.; Pieterse, C.M. Significance of inducible defense-related proteins in infected plants. Annu. Rev. Phytopathol. 2006, 44, 135-162. [CrossRef]

48. Brandazza, A.; Angeli, S.; Tegoni, M.; Cambillau, C.; Pelosi, P. Plant stress proteins of the thaumatin-like family discovered in animals. FEBS Lett. 2004, 572,3-7. [CrossRef]

49. Jayasankar, S.; Li, Z.; Gray, D.J. Constitutive expression of Vitis vinifera thaumatin-like protein after in vitro selection and its role in anthracnose resistance. Funct. Plant Biol. 2003, 30, 1105-1115. [CrossRef]

50. Monteiro, S.; Barakat, M.; Piçarra-Pereira, M.A.; Teixeira, A.R.; Ferreira, R.B. Osmotin and thaumatin from grape: A putative general defense mechanism against pathogenic fungi. Phytopathology 2003, 93, 1505-1512. [CrossRef]

51. Menu-Bouaouiche, L.; Vriet, C.; Peumans, W.J.; Barre, A.; Van Damme, E.J.; Rougé, P. A molecular basis for the endo- $\beta 1$, 3-glucanase activity of the thaumatin-like proteins from edible fruits. Biochimie 2003, 85, 123-131. [CrossRef]

52. Derckel, J.P.; Baillieul, F.; Manteau, S.; Audran, J.C.; Haye, B.; Lambert, B.; Legendre, L. Differential induction of grapevine defenses by two strains of Botrytis cinerea. Phytopathology 1999, 89, 197-203. [CrossRef] [PubMed]

53. Dadakova, K.; Havelkova, M.; Kurkova, B.; Tlolkova, I.; Kasparovsky, T.; Zdrahal, Z.; Lochman, J. Proteome and transcript analysis of Vitis vinifera cell cultures subjected to Botrytis cinerea infection. J. Proteom. 2015, 119, 143-153. [CrossRef] [PubMed]

54. Giacomelli, L.; Nanni, V.; Lenzi, L.; Zhuang, J.; Serra, M.D.; Banfield, M.J.; Town, C.D.; Silverstein, K.A.T.; Baraldi, E.; Moser, C. Identification and characterization of the defensin-like gene family of grapevine. Mol. Plant Microbe Interact. 2012, 25, 1118-1131. [CrossRef]

55. Bellée, A.; Comont, G.; Nivault, A.; Abou-Mansour, E.; Coppin, C.; Dufour, M.C.; Corio-Costet, M.F. Life traits of four Botryosphaeriaceae species and molecular responses of different grapevine cultivars or hybrids. Plant Pathol. 2017, 66, 763-776. [CrossRef]

56. Girault, T.; François, J.; Rogniaux, H.; Pascal, S.; Delrot, S.; Coutos-Thévenot, P.; Gomès, E. Exogenous application of a lipid transfer protein-jasmonic acid complex induces protection of grapevine towards infection by Botrytis cinerea. Plant Physiol. Biochem. 2008, 46, 140-149. [CrossRef]

57. Thaler, J.S.; Humphrey, P.T.; Whiteman, N.K. Evolution of jasmonate and salicylate signal crosstalk. Trends Plant Sci. 2012, 17, 260-270. [CrossRef]

58. MacDonald, M.J.; D'Cunha, G.B. A modern view of phenylalanine ammonia lyase. Biochem. Cell Biol. 2007, 85, 273-282. [CrossRef]

59. Dixon, R.A.; Paiva, N.L. Stress-induced phenylpropanoid metabolism. Plant Cell 1995, 7, 1085. [CrossRef]

60. Chong, J.; Poutaraud, A.; Hugueney, P. Metabolism and roles of stilbenes in plants. Plant Sci. 2009, 177, 143-155. [CrossRef]

61. Birkenbihl, R.P.; Diezel, C.; Somssich, I.E. Arabidopsis WRKY33 is a key transcriptional regulator of hormonal and metabolic responses toward Botrytis cinerea infection. Plant Physiol. 2012, 159, 266-285. [CrossRef] [PubMed]

62. Windram, O.; Madhou, P.; McHattie, S.; Hill, C.; Hickman, R.; Cooke, E.; Jenkins, D.J.; Penfold, C.A.; Baxter, L.; Breeze, E.; et al. Arabidopsis defense against Botrytis cinerea: Chronology and regulation deciphered by high-resolution temporal transcriptomic analysis. Plant Cell 2012, 24, 3530-3557. [CrossRef] [PubMed]

63. Ogasawara, Y.; Kaya, H.; Hiraoka, G.; Yumoto, F.; Kimura, S.; Kadota, Y.; Hishinuma, H.; Senzaki, E.; Yamagoe, S.; Nagata, K.; et al. Synergistic activation of the Arabidopsis NADPH oxidase AtrbohD by $\mathrm{Ca}^{2+}$ and phosphorylation. J. Biol. Chem. 2008, 283, 8885-8892. [CrossRef] [PubMed]

64. Tena, G.; Boudsocq, M.; Sheen, J. Protein kinase signaling networks in plant innate immunity. Curr. Opin. Plant Biol. 2011, 14, 519-529. [CrossRef] [PubMed]

65. Boudsocq, M.; Sheen, J. CDPKs in immune and stress signaling. Trends Plant Sci. 2013, 18, 30-40. [CrossRef] [PubMed]

66. Chiasson, D.; Ekengren, S.K.; Martin, G.B.; Dobney, S.L.; Snedden, W.A. Calmodulin-like proteins from Arabidopsis and tomato are involved in host defense against Pseudomonas syringae pv. tomato. Plant Mol. Biol. 2005, 58, 887-897. [CrossRef]

67. Mzid, R.; Marchive, C.; Blancard, D.; Deluc, L.; Barrieu, F.; Corio-Costet, M.F.; Drira, D.; Hamdi, S.; Lauvergeat, V. Overexpression of VvWRKY2 in tobacco enhances broad resistance to necrotrophic fungal pathogens. Physiol. Plant 2007, 131, 434-447. [CrossRef] 
68. Guillaumie, S.; Mzid, R.; Méchin, V.; Léon, C.; Hichri, I.; Destrac-Irvine, A.; Trossat-Magnin, C.; Delrot, S.; Lauvergeat, V. The grapevine transcription factor WRKY2 influences the lignin pathway and xylem development in tobacco. Plant Mol. Biol. 2010, 72, 215-234. [CrossRef]

69. Travadon, R.; Rolshausen, P.E.; Gubler, W.D.; Cadle-Davidson, L.; Baumgartner, K. Susceptibility of cultivated and wild Vitis spp. to wood infection by fungal trunk pathogens. Plant Dis. 2013, 97, 1529-1536. [CrossRef]

70. Gambino, G.; Perrone, I.; Gribaudo, I. A rapid and effective method for RNA extraction from different tissues of grapevine and other woody plants. Phytochem. Anal. 2008, 19, 520-525. [CrossRef]

71. Andrews, S. FastQC: A Quality Control Tool for High Throughput Sequence Data. 2010. Available online: https://www.bioinformatics.babraham.ac.uk/projects/fastqc/ (accessed on 2 December 2019).

72. Martin, M. Cutadapt removes adapter sequences from high-throughput sequencing reads. EMBnet J. 2011, 17, 10-12. [CrossRef]

73. Wingett, S.W.; Andrews, S. FastQ Screen: A tool for multi-genome mapping and quality control. F1000Research 2018, 7, 1338. [CrossRef] [PubMed]

74. Dobin, A.; Davis, C.A.; Schlesinger, F.; Drenkow, J.; Zaleski, C.; Jha, S.; Batut, P.; Chaisson, M.; Gingeras, T.R. STAR: Ultrafast universal RNA-seq aligner. Bioinformatics 2013, 29, 15-21. [CrossRef] [PubMed]

75. Li, B.; Dewey, C.N. RSEM: Accurate transcript quantification from RNA-Seq data with or without a reference genome. BMC Bioinform. 2011, 12, 323. [CrossRef]

76. Ewels, P.; Magnusson, M.; Lundin, S.; Käller, M. MultiQC: Summarize analysis results for multiple tools and samples in a single report. Bioinformatics 2016, 32, 3047-3048. [CrossRef]

77. Robinson, M.D.; McCarthy, D.J.; Smyth, G.K. edgeR: A Bioconductor package for differential expression analysis of digital gene expression data. Bioinformatics 2010, 26, 139-140. [CrossRef]

78. Nueda, M.J.; Tarazona, S.; Conesa, A. Next maSigPro: Updating maSigPro bioconductor package for RNA-seq time series. Bioinformatics 2014, 30, 2598-2602. [CrossRef]

79. Zaini, P.A.; Nascimento, R.; Gouran, H.; Cantu, D.; Chakraborty, S.; Phu, M.; Goulart, L.R.; Dandekar, A.M. Molecular profiling of Pierce's disease outlines the response circuitry of Vitis vinifera to Xylella fastidiosa infection. Front. Plant Sci. 2018, 9, 771. [CrossRef]

(C) 2019 by the authors. Licensee MDPI, Basel, Switzerland. This article is an open access article distributed under the terms and conditions of the Creative Commons Attribution (CC BY) license (http://creativecommons.org/licenses/by/4.0/). 